\title{
One-Point Covalent Immobilization of Enzymes on Glyoxyl Agarose with Minimal Physico-Chemical Modification: Immobilized "Native Enzymes"
}

\author{
Jose M. Guisan, Fernando López-Gallego, Juan M. Bolivar, \\ Javier Rocha-Martín, and Gloria Fernandez-Lorente
}

\begin{abstract}
The immobilization of soluble enzymes inside the porous structure of a preexisting support is one of the most interesting techniques to prepare heterogeneous biocatalysts. The main cause of inactivation of these biocatalysts is the distortion of the tridimensional structure of the immobilized enzymes. In some cases, immobilization of enzymes on preexisting supports can be used in order to improve its functional properties: stabilization by multipoint covalent immobilization, hyper-activation, and stabilization of lipases by interfacial adsorption on hydrophobic supports, etc. In other cases, the properties of the enzyme can be modified by additional interactions of the enzyme surface with the support surface: hydrophobic or electrostatic interactions.

In all cases, it would be very interesting to evaluate the intrinsic tridimensional stability of native industrial enzymes. Under drastic experimental conditions, soluble enzymes may undergo undesirable aggregations, and the tridimensional stability of one enzyme is more accurately evaluated by using immobilized native enzymes. That is, immobilized derivatives associated to a minimal chemical modification of the enzyme surface placed in the proximity of a fully hydrophilic and inert support surfaces. In this chapter, the immobilization of enzymes with minimal physicochemical modification on glyoxyl agarose supports is proposed. At $\mathrm{pH} \mathrm{8.5,} \mathrm{the} \mathrm{unique} \mathrm{reactive} \mathrm{amino} \mathrm{group} \mathrm{on} \mathrm{the} \mathrm{enzyme} \mathrm{surface} \mathrm{is} \mathrm{the} \mathrm{N-terminus.}$ At the end of the immobilization, mild borohydride reduction, the primary amino terminus is simply converted into a secondary amino group, with similar physical properties, and aldehyde groups on the supports are converted into fully inert hydroxyl groups. The preparation of immobilized derivatives of penicillin $\mathrm{G}$ acylase (PGA) with identical properties (activity and stability) that one of the soluble enzyme is reported: preparation of immobilized native PGA.
\end{abstract}

Key words Covalent immobilization, Glyoxyl agarose, Native enzymes, N-terminus, Thiolated compounds, 2-picoline borane 
1 Introduction

1.1 Immobilization of Enzymesinside Porous Supports: Stabilizing Effects
Immobilization of enzymes via a firm attachment to the internal surface of porous supports may exert interesting stabilizing effects regarding the corresponding soluble enzymes [1]. The immobilized enzyme molecules cannot undergo aggregations (at high temperatures, in the presence of organic cosolvents, etc.), and they cannot interact with interfaces in stirred reactors (oxygen bubbles, immiscible solvents in biphasic reactors, etc.) (Fig. 1) [2]. Immobilized enzyme molecules can be only inactivated by distortions of their tridimensional structure. Under rare very drastic conditions (e.g., very high temperatures), they could also be inactivated by chemical modification of key residues.

On the contrary, soluble enzymes can be inactivated by aggregation and by interaction with interfaces. Very mild enzyme aggregations may even be stabilizing ones but drastic aggregations (heat, solvents) are highly destabilizing ones [3]. In this way, enzyme immobilization inside porous supports can be associated with interesting stabilizations. This stabilization is common to any immobilization protocol of a given enzyme inside a porous structure, and it does not reflect the accuracy of a given immobilization protocol. Different immobilization protocols should be compared between themselves and, if possible, an immobilized derivative of the "native enzyme" should also be compared. In this way, the structural stabilization/destabilization of different derivatives of a given

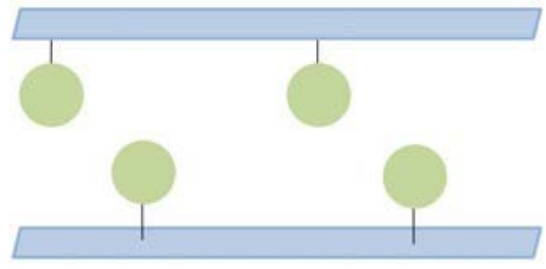

\section{Immobilized enzymes inside a porous support}

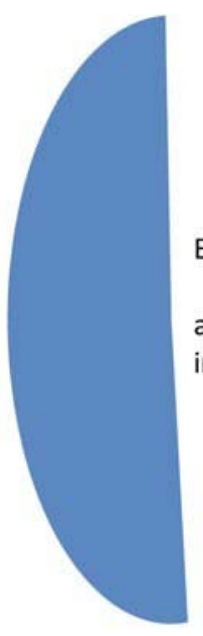

External interface:

air, oxygen, immiscible solvents, etc.

- enzyme aggregations are impossible

- Interaction of enzymes with external interfaces is impossible

- The main cause of inactivation in the distortion of the 3D structure

- At very high temperatures some chemical modifications may occur

Fig. 1 Immobilized enzyme molecules inside the porous structure of a support 
1.2 The Use of

Soluble Enzymes as "Blanks" to Test the Functional Properties of Enzymes Immobilized Inside Porous Supports

\subsection{Immobilized} "Native Enzymes"

\subsection{Immobilization of Enzymes on Glyoxyl Supports}

enzyme could be correctly evaluated. The best immobilization protocol would be the one promoting the most intense structural stabilization of a given enzyme [2].

In many cases, immobilized enzyme derivatives are compared to soluble enzymes in order to test the stabilizing effect of a given immobilization protocol [4]. This could be fairly correct when the blank is a very diluted solution of a pure enzyme incubated at moderate temperatures in the absence of stirring (aggregations are minimized). However, when the blank is a concentrated crude extract incubated at high temperatures and/or in the presence of organic cosolvents, the comparison soluble vs. immobilized enzyme may be clearly incorrect as commented above. A suitable blank of an immobilized "native enzyme" would be very convenient. Obviously, immobilization of an enzyme inside a porous supports implies a certain modification of the native enzyme [5]. However, it is possible to immobilize the enzyme with minimal chemical and physical modification.

One-point covalent immobilization of enzymes on aldehydeagarose supports (at slightly alkaline $\mathrm{pH}$ ) is here proposed as a suitable protocol to prepare immobilized "native enzymes" (Fig. 2). After immobilization, derivatives are reduced with sodium borohydride. In this way, the primary amino terminus of the native enzyme is simply converted into a secondary amino group (with very similar physical properties), and the enzyme surface remains unaltered in the proximity of a fully inert and highly hydrophilic internal surface of agarose gels.

Highly activated glyoxyl supports rapidly immobilize enzymes at $\mathrm{pH} 10$ (where the $\varepsilon$-amino groups of the Lys residues placed on the enzyme surface are very reactive), and stabilize them by multipoint covalent attachment (see Chapter 5) [6]. However, glyoxyl supports do not immobilize enzymes at $\mathrm{pH} 8.5$ where the $\mathrm{N}$-terminus is the unique reactive amino group on the enzyme surface (nonprotonated form) [7]. One-point attachment between one amino group and one linear aldehyde group yields a very unstable Schiff's base and the enzymes do not become immobilized on the support (Fig. 3).

However, these single Schiff's bases can be stabilized in order to promote stable one-point enzyme-agarose immobilizations (Fig. 3):

(a) By selective reduction of Schiff's bases to very stable secondary amino bonds in the presence of very mild reducing agents such as cyanoborohydride or 2-picoline borane (see Note I) [8]. 
IMMOBILIZED “NATIVE” ENZYME
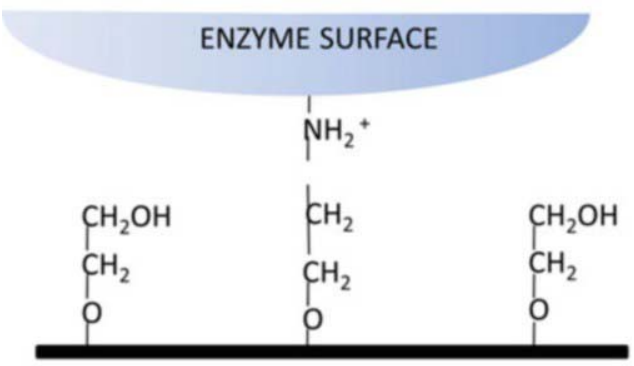

AGAROSE SUPPORT
SOLUBLE NATIVE ENZYME

ENZYME SURFACE

$\mathrm{NH}_{3}{ }^{+}$

Fig. 2 Immobilized native enzymes may be almost identical to soluble native enzymes

THE ONE-POINT AMINO-ALDEHYDE ATTACHMENT
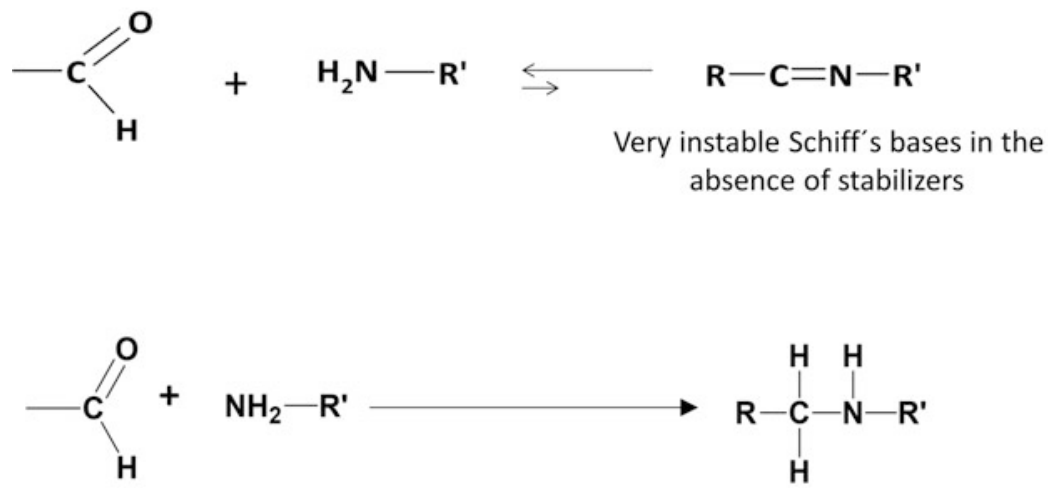

Secondary amino bonds in the presence of very mild reducing agents

Fig. 3 One-point amino-aldehyde attachment in the absence or in the presence of stabilizers

(b) By the formation of stable complexes between Schiff's bases and thiolated compounds such as acetyl-cysteine, mercaptoethanol, or dithiothreitol (DTT) [7].

After the one-point covalent immobilization, the immobilized derivatives have to be reduced with sodium borohydride in order to reduce Schiff's bases to secondary amino groups and to reduce remaining aldehyde groups into hydroxyl ones [7].

\subsection{Structural}

Studies of Native

Enzymes Under

Nonconventional Conditions
Nowadays, in addition to their key physiological role, enzymes have also become relevant industrial catalysts. In this way, structurefunction studies of enzymes under a great variety of experimental conditions, not only physiological ones, have become very interesting: high temperatures, presence of cosolvents, anhydrous solvents, solvent-free reaction systems (e.g., ethanolysis of oils), ionic liquids, etc. Some experimental techniques, solid-state nuclear magnetic 
resonance (NMR), circular dichroism, fluorescence, etc., could be very useful to study conformational studies of immobilized enzymes. For example, agarose gels are transparent supports (they only promote slight "light scattering" but they do not adsorb radiations, except IR radiation) [9, 10]. Agarose gels seem very suitable for structural studies of immobilized enzymes. Most of these techniques require the use of high enzyme concentrations (e.g., NMR) and, in some case, soluble enzymes could not be used because of aggregation problems. A suitable derivative of a highly concentrated immobilized "native enzyme" would be necessary to perform solid-state NMR [11].

\section{Materials}

1. Commercial highly activated glyoxyl-6\% agarose gels (High Density Glyoxal 6BCL, Agarose Bead Technologies, Madrid, Spain).

2. Highly activated glyoxyl-6\% agarose gels can be alsoprepared as described in [12] (or see Chapter 5).

3. Commercial penicillin $\mathrm{G}$ acylase (penicillin amidase), PGA, from Escherichia coli.

4. Reducing agents: 2-picoline borane (2-methylpyridine borane complex) and sodium borohydride.

5. DL-Dithiothreitol (DTT, Cleland's reagent).

6. 6-nitro-3-phenylacetamidobenzoic acid (NIPAB).

3 Methods

\subsection{PGA Activity Assay}

1. Principle. Activity was determined by measuring the increase in absorbance in the reaction mixture promoted by the release of 3-amino-6-nitrobenzoic acid (molar extinction coefficient $8980 \mathrm{M}^{-1} \mathrm{~cm}^{-1}$ at $405 \mathrm{~nm}, \mathrm{pH} 7.5$, and $25^{\circ} \mathrm{C}$ ).

2. Add a suitable amount of enzyme to a spectrophotometric cell containing $2 \mathrm{~mL}$ of $0.2 \mathrm{mM}$ NIPAB dissolved in sodium phosphate buffer at $\mathrm{pH}$ 7.5.

3. Monitor absorbance increase and calculate activity using the initial linear reaction rate. One NIPAB unit was defined as the amount of enzyme required to hydrolyze $1 \mu \mathrm{mol}$ of NIPAB per minute at $\mathrm{pH} 7.5$ and $25^{\circ} \mathrm{C}$. This unit corresponds to $2.4 \mathrm{IU}$ of PGA: this amount of enzyme is able to liberate $2.4 \mu \mathrm{mols}$ of phenyl acetic acid by hydrolysis of NIPAB by penicillin $\mathrm{G}$ at $\mathrm{pH} 8.0$ and $37^{\circ} \mathrm{C} .1 \mathrm{mg}$ of commercial PGA preparation has 4 NIPAB units per $\mathrm{mg}$ of protein ( $25 \%$ purity). 
3.2 One-Point

Covalent

Immobilization of

Penicillin G Acylase

(PGA) on Glyoxyl

Agarose

\subsubsection{Standard}

Immobilization in the

Absence of Stabilizers

3.2.2 Standard

Immobilization in the

Presence of 2-Picoline

Borane

\subsubsection{Standard} Immobilization in the Presence of DTT
PGA is a heterodimeric enzyme containing two N-terminus. However, one of them is buried inside the active center and it is not exposed to the medium. Hence, PGA behaves as a monomeric enzyme with only one exposed amino terminus [13].

1. $3 \mathrm{~g}$ of wet glyoxyl- $6 \%$ agarose gel was added to $30 \mathrm{~mL}$ of PGA solution $(0.2 \mathrm{mg}$ of commercial enzyme per $\mathrm{mL}$ of $0.1 \mathrm{M}$ bicarbonate buffer $\mathrm{pH}$ 8.5). This is eight NIPAB units were offered per wet gram of support (in order to prevent diffusional limitations).

2. Leave the suspension under very gentle stirring (see Note 2) (e.g., in a rotating shaker) for $10 \mathrm{~h}$ at $4{ }^{\circ} \mathrm{C}$. Take samples of supernatant and suspension for follow immobilization (Subheading 3.3).

3. After $10 \mathrm{~h}$, the suspension was reduced by adding $11 \mathrm{mg}$ of sodium borohydride, and the reaction was performed under very gentle stirring for $30 \mathrm{~min}$.

4. Then derivatives were filtered and washed with distilled water and finally with $50 \mathrm{mM}$ phosphate at $\mathrm{pH} 8.0$. The wet immobilized derivatives were stored at $4{ }^{\circ} \mathrm{C}$.

1. $3 \mathrm{~g}$ of wet glyoxyl- $6 \%$ agarose gel was added to $30 \mathrm{~mL}$ of PGA solution $(0.2 \mathrm{mg}$ of commercial enzyme per $\mathrm{mL}$ of $0.1 \mathrm{M}$ bicarbonate buffer $\mathrm{pH} 8.5$ containing $20 \mathrm{mM}$ of 2-picoline borane).

2. Leave the suspension under very gentle stirring for $10 \mathrm{~h}$ at 4 ${ }^{\circ} \mathrm{C}$. Take samples of supernatant and suspension for follow immobilization (Subheading 3.3).

3. After $10 \mathrm{~h}$, the suspension was reduced by adding $30 \mathrm{mg}$ of sodium borohydride, and the reaction was performed under very gentle stirring for $30 \mathrm{~min}$.

4. Then, derivatives were filtered and washed with distilled water and finally with $50 \mathrm{mM}$ phosphate $\mathrm{pH}$ 8.0. The wet immobilized derivatives were stored at $4{ }^{\circ} \mathrm{C}$.

1. $3 \mathrm{~g}$ of wet glyoxyl- $6 \%$ agarose gel was added to $30 \mathrm{~mL}$ of PGA solution $(0.2 \mathrm{mg}$ of commercial enzyme per $\mathrm{mL}$ of $0.1 \mathrm{M}$ bicarbonate buffer $\mathrm{pH} 8.5$ containing $50 \mathrm{mM}$ of DTT).

2. Leave the suspension under very gentle stirring for $10 \mathrm{~h}$ at 4 ${ }^{\circ} \mathrm{C}$. Take samples of supernatant and suspension for follow immobilization (Subheading 3.3). 


\subsection{Time-Course of One-Point Covalent Immobilizations}

\subsubsection{Principle}

3.3.2 Steps

3.3.3 Results Analysis
3. After $10 \mathrm{~h}$, the suspension was reduced by adding $30 \mathrm{mg}$ of sodium borohydride, and the reaction was performed under very gentle stirring for $30 \mathrm{~min}$.

4. Then, derivatives were filtered and washed with distilled water and finally with $50 \mathrm{mM}$ phosphate $\mathrm{pH}$ 8.0. The wet immobilized derivatives were stored at $4{ }^{\circ} \mathrm{C}$.

Time-courses of immobilization were followed by measuring the enzymatic activity of the supernatants of the immobilization suspensions (see Fig. 4).

1. Incubate blanks of enzyme solutions without activated supports under the same conditions of immobilization (Subheading 3.2).

2. Measure enzymatic activity from blanks and samples from immobilization (Subheading 3.2).

Figure 4 shows the output of the analysis. These blanks remain fully active during the whole immobilization and hence the decrease in the activity of the supernatants of the immobilization suspensions exactly represents the percentage of enzyme that has been incorporated into the solid support at different times.

The activity of the supernatant of immobilization suspension in the absence of stabilizers remains fully active during $4 \mathrm{~h}$. This means that immobilization is not possible because of the instability of onepoint Schiff's base.

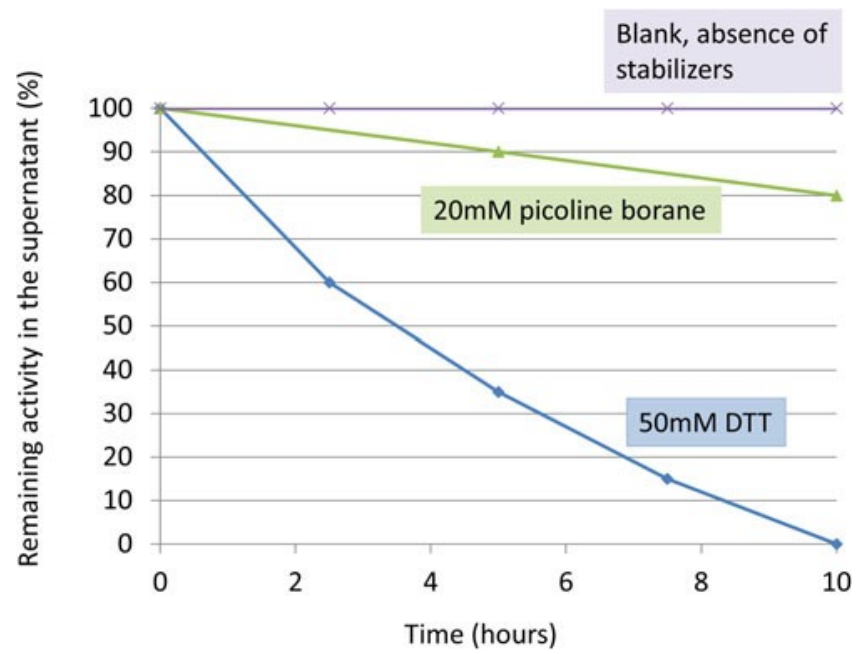

Fig. 4 Time-course of one-point covalent immobilizations of PGA on glyoxyl agarose at $\mathrm{pH} 8.5$ and $4{ }^{\circ} \mathrm{C}$ 
3.4 Thermal Inactivation

3.4.1 Steps

3.4.2 Analysis

The activity of the supernatant of immobilization suspension in the presence of 2-picoline borane slightly decreases down to $80 \%$ after $10 \mathrm{~h}$. It seems that reduction of Schiff's bases by 2-picoline borane is possible, but it is very slow. A low loaded one-point covalent immobilized derivative can be obtained.

The activity of the supernatant of the immobilization suspension in the presence of DTT decreases down to less than 5\% after $10 \mathrm{~h}$. It seems that the stabilization of Schiff's bases by complexation with DTT is possible, and it is fast enough (see Note 3). This is the optimal protocol to get one-point covalent immobilization of monomeric enzymes.

1. One wet gram of each immobilized derivative was suspended in $10 \mathrm{~mL}$ of phosphate $50 \mathrm{mM}$ at $\mathrm{pH} 8.0$, and $1 \mathrm{mg}$ of a commercial sample of the soluble enzyme was diluted in $10 \mathrm{~mL}$ of phosphate $50 \mathrm{mM}$ at $\mathrm{pH} 8.0$.

2. Measure the initial activity of all preparations.

3. Incubate the immobilized derivatives and the soluble enzyme at $50{ }^{\circ} \mathrm{C}$. At different times, aliquots $(100 \mu \mathrm{L})$ of the suspensions and of the solution were withdrawn and assayed.

The time-courses of thermal inactivation of both derivatives and of soluble enzyme were identical (Fig. 5). The one-point covalently attached derivatives exhibit the same activity and stability of soluble enzyme under moderate experimental conditions. They seem to be immobilized "native enzymes," and they are very useful to test the intrinsic 3D stability of native enzyme against any type of denaturing agent under more drastic experimental conditions (temperature, $\mathrm{pH}$, cosolvents, ionic liquids, organic solvents, etc.). By using highly loaded immobilized derivatives of "native enzymes," a number of interesting structural studies could also be performed.

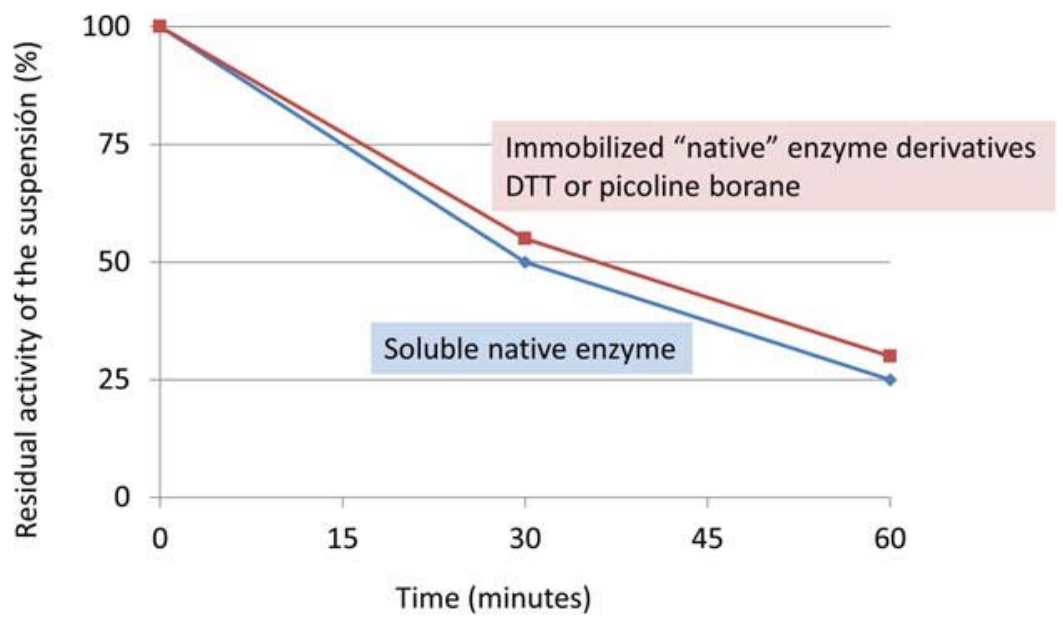

Fig. 5 Time-course of thermal inactivation at $\mathrm{pH} 8.0$ and $50^{\circ} \mathrm{C}$ 


\section{PRELIMINARY EVALUATION OF NOVEL INDUSTRIAL ENZYMES}

\section{EVALUATION ON INTRINSIC FUNCTIONAL PROPERTIES OF INDUSTRIAL ENZYMES BY USING CRUDE EXTRACTS}

a.- immobilized proteins are fully dispersed on the support surface

b.- enzyme-protein interactions are impossible

c.- stability-selectivity are independent from the purification factor

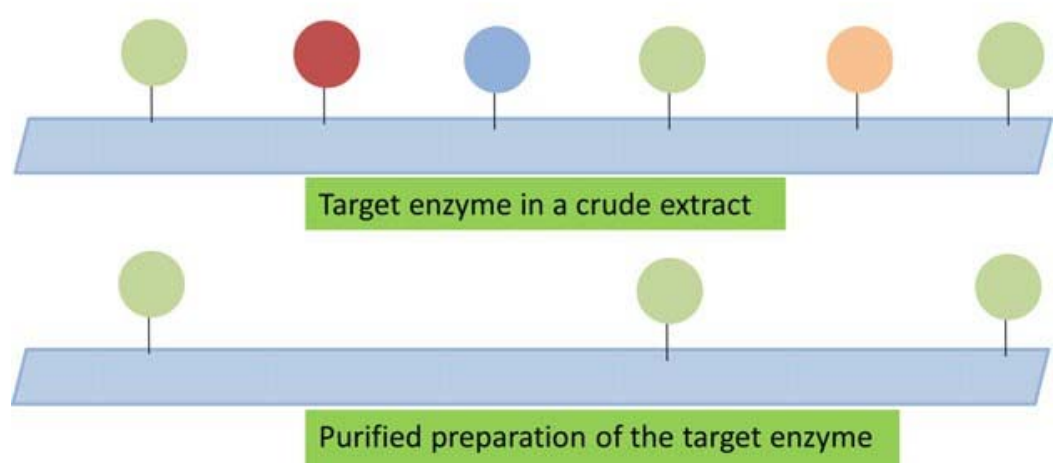

Fig. 6 Immobilization of crude extracts prevents any aggregation process

3.5 Evaluation of

Novel Potential Industrial Enzymes by Using Crude Protein Extracts
The one-point covalent immobilization proposed here can also be used to immobilize protein crude extracts (Fig. 6). After this immobilization, all proteins (including the target enzyme) are fully dispersed on the support surface, and they cannot interact ones with others. In addition, they undergo minimal physicochem- ical modifications. In this way, the observed stability and selectivity of the target enzyme exactly represent the intrinsic properties of the native enzyme without the need of a preliminary complex purification.

4 Notes

1. In addition to 2-picoline borane, other mild reducing agents could be used (e.g., cyanoborohydride and triacetoxyborohydride). However, most of them are highly toxic and poorly soluble in water [14]. On the contrary, 2-picoline borane is not toxic, and it can be dissolved up to $20 \mathrm{mM}$ in water.

2. Agarose gels are very resistant to mechanical stirring, but they are easily broken under magnetic stirring. Very gentle sitting of agarose suspensions should be done. Rotating shakers can be very useful.

3. Multimeric enzymes may have two or more amino terminus within of one plane and hence they could be attached to the support, in the absence of stabilizers, via a simultaneous 
two-point covalent attachment associated to the stabilization of the quaternary structure [15]. One-point covalent immobilization can be achieved by using DTT and an excess of the soluble enzyme with very short immobilization times (30 min$1 \mathrm{~h})$ at $4{ }^{\circ} \mathrm{C}$ in order to prevent the two-point immobilization. Another alternative may be the use of lowly activated supports (e.g., $20 \mu \mathrm{Eqs}$ of aldehyde groups per gram of support).

References 
1. Zhao XS, Bao XY, Guo W, Lee FY (2006) Immobilizing catalysts on porous materials. Mater Today 9:32-39

2. Mateo C, Palomo JM, Fernandez-Lorente G, Guisan JM, Fernandez-Lafuente R (2007) Improvement of enzyme activity, stability and selectivity via immobilization techniques. Enzym Microb Technol 40:1451-1463

3. Schoevaart R, Van Langen LM (2005) Cross- linked enzyme aggregates (CLEAs): a novel and versatile method for enzyme immobiliza- tion (a review). Biocatal Biotransformation 23:141-147

4. Liese A, Hilterhaus L (2013) Evaluation of immobilized enzymes for industrial applica- tions. Chem Soc Rev 42:6236-6249

5. Secundo F (2013) Conformational changes of enzymes upon immobilisation. Chem Soc Rev 42:6250-6261

6. Gloria F-L, Fernando L-G, Juan MB, Javier R-M, Sonia M-P, Jose MG (2015) Immobili- zation of proteins on highly activated glyoxyl supports: dramatic increase of the enzyme sta- bility via multipoint immobilization on preexisting carriers. Curr Org Chem 19:1719-1731

7. Bolivar JM, López-Gallego F, Godoy C, Rodri- gues DS, Rodrigues RC, Batalla P, Rocha- Martín J, Mateo C, Giordano RLC, Guisán JM (2009) The presence of thiolated com- pounds allows the immobilization of enzymes on glyoxyl agarose at mild $\mathrm{pH}$ values: new strategies of stabilization by multipoint cova- lent attachment. Enzym Microb Technol 45:477-483

8. Orrego H, Romero-Fernández M, Millán- Linares MDC, Yust MDM, Guisán JM, Rocha-Martin J (2018) Stabilization of 
enzymes by multipoint covalent attachment on aldehyde-supports: 2-Picoline borane as an alternative reducing agent. Catalysts 8:333

9. Ben'itez-Mateos AI, Nidetzky B, Bolivar JM, López-Gallego F (2018) Single-particle studies to advance the characterization of heteroge- neous biocatalysts.

ChemCatChem 10:654-665

10. Bolivar JM, Eisl I, Nidetzky B (2016) Advanced characterization of immobilized enzymes as heterogeneous biocatalysts. Catal Today 259:66-80

11. Varghese S, Halling PJ, Hfussinger D, Wim- peris S (2016) High-resolution structural char-acterization of a heterogeneous biocatalyst using solid-state NMR. J Phys Chem C 120:28717-28726

12. Guisán JM (1988) Aldehyde-agarose gels as activated supports for immobilization- stabilization of enzymes. Enzym Microb Tech- nol 10:375-382

13. Duggleby HJ, Tolley SP, Hill CP, Dodson EJ, Dodson G, Moody PCE (1995) Penicillin acy- lase has a singleamino-acid catalytic centre. Nature 373:264-268

14. Sato S, Sakamoto T, Miyazawa E, KikugawaY (2004) One-pot reductive amination of alde- hydes and ketones with a-picoline-borane in methanol, in water, and in neat conditions. Tetrahedron 60:7899-7906

15. Bolivar JM, Rocha-Martin J, Mateo C, Cava F, Berenguer J, Vega D, Fernandez-Lafuente R, Guisan JM (2009) Purification and stabiliza- tion of a glutamate dehygrogenase from Ther-mus thermophilus via oriented multisubunit plus multipoint covalent immobilization. J Mol Catal B Enzym 58:158-163 